\title{
ANALYSIS OF RELATIONSHIPS BETWEEN FATTENING AND SLAUGHTER PERFORMANCE OF PIGS AND THE LEVEL OF INTRAMUSCULAR FAT (IMF) IN LONGISSIMUS DORSI MUSCLE*
}

\author{
Mirosław Tyra, Grzegorz Żak \\ Department of Animal Genetics and Breeding, National Research Institute of Animal Production, \\ 32-083 Balice n. Kraków, Poland
}

\begin{abstract}
The aim of the study was to determine the level of basic fattening and slaughter traits (growth rate, level of meatiness and fatness, age at slaughter) depending on different levels of intramuscular fat that determine different sensory perceptions of consumers. Subjects were $\mathbf{4 4 3 0}$ gilts from pedigree farms, which were tested in performance stations. The breed composition of the animals was as follows (head): Polish Large White - 1240, Polish Landrace - 2083, Pulawska - 104, Hampshire - 35, Duroc - 152, Pietrain - 208, line 990 - 608. Animals were kept in individual pens and fed standard diets. Intramuscular fat (IMF) content of the longissimus dorsi muscle was determined by Soxhlet using the SOXTHERM SOX 406 system (Gerhardt). The level of IMF served as a basis for dividing the test animals into three groups: below $2 \%$ (group I), between $2 \%$ and $3 \%$ (group II) and above 3\% (group III). Animal breed had the highest and highly significant effect on the level of all traits analysed. As regards age at slaughter and carcass meat percentage, an interaction was found between animal breed and the group factor determined based on IMF level $(P \leq 0.001)$. The factor expressed as IMF group had no effect on the level of analysed traits $(P>0.05)$. Therefore, the results of this analysis concerning the parameters obtained from live evaluation do not permit these data to be used in selection for improved IMF levels. The high rate of lean deposition in the modern breeds prevented genetic differences in the level of IMF to fully manifest themselves at a slaughter weight of about $100 \mathrm{~kg}$. This unfavourable information leads one to look for other factors that determine variation of this trait.
\end{abstract}

Key words: pigs, performance, intramuscular fat, longisimus dorsi muscle

Consumers judge the quality of fattening pigs based on not only muscle content of individual cuts but also the quality characteristics of their meat. This issue takes on special significance today because one-sided selection for meat content resulted in a population whose muscle content exceeds $55 \%$ but its meat quality fails to meet required palatability, tenderness and juiciness. One trait that largely determines the parameters mentioned above is the intramuscular fat content (IMF) (Fernandez et al., 1999; Schwab et al., 2006). It is also of note that the presence of intramuscular fat enhances taste properties of meat while having a beneficial effect on the technological processes related to heat treatment of the meat.

Research on the Polish population of pedigree animals revealed that intramuscular fat levels are low and show a downward trend (Tyra and Orzechowska, 2006;

*This research was supported by the National Science Center, Grant no. N R12 005910. 
Tyra and Żak, 2010). It should be noted that the low level of intramuscular fat also impacts the economics of pork production (Koćwin-Podsiadła et al., 2006) as it reveals meat quality defects that prevent optimum carcass utilization. In this connection, it seemed appropriate to undertake a study to determine the ranges of muscling and fatness in which IMF content is at the most beneficial level. This approach would make it possible to determine threshold ranges for fattening and slaughter traits of good-quality meat in terms of intramuscular fat. Positive results of this research would provide selective breeders with a tool enabling IMF to be gradually increased in the active population and these advances to be transferred to the entire population of pigs in Poland. Therefore, the aim of this study was to determine the level of basic fattening and slaughter traits for various IMF levels that determine different sensory experiences of the consumers.

\section{Material and methods}

Subjects were 4430 gilts from pedigree farms, which were tested in performance stations. Most animals represented the Polish Large White (PLW; 1240 gilts) and the Polish Landrace breeds (PL; 2083 gilts). Other breeds raised in Poland were also studied, but their numbers were limited because they are not strongly represented in pedigree farms (104 Puławska, 35 Hampshire, 152 Duroc, 208 Pietrain and 608 line 990 (L990) gilts).

Animals were housed in individual pens and fed a standard diet containing an average of $13.50 \mathrm{MJ} / \mathrm{Kg}$ metabolizable energy and from 17 to $19 \%$ crude protein. Daily gains were recorded during fattening from 30 to $100 \mathrm{~kg}$ of body weight. Gilts were slaughtered at $100 \mathrm{~kg}$ body weight and their carcasses were dissected after 24-h chilling. The parameters obtained during dissection served as indicators of fatness and muscling. Average backfat thickness calculated from 5 measurements (at the thickest point over the shoulder; on the back above the joint between the last thoracic and first lumbar vertebrae; at three points over the loin: above the rostral edge (loin I), above the middle (loin II), and above the caudal edge (loin III) of gluteal muscle cross-section) was used as the fatness indicator. Muscling was determined by estimating carcass meat content using the following formula:

where:

$$
y=1.745 x_{1}+0.836 x_{2}+0.157 x_{3}-1.884
$$

$y$ - calculated meat content $(\mathrm{kg})$,

$x_{1}$ - ham without skin and backfat $(\mathrm{kg})$,

$x_{2}$ - loin without backfat + tenderloin $(\mathrm{kg})$,

$x_{3}$ - double loin eye width + loin eye height $(2 \mathrm{~A}+\mathrm{B})(\mathrm{cm})$.

The meat content of primal cuts, calculated from this formula, was expressed as percentage of chilled carcass weight. The IMF content of meat was determined as raw fat using Soxhlet extraction with fat solvents (Soxtherm SOX 406, Gerhardt). Test samples were taken from the middle part of longissimus dorsi cross-sectional area behind the last rib. The last parameter served as a basis for dividing the test 
material into three groups, in which the IMF content of the longissimus dorsi muscle was $<2 \%$ (group I), $2-3 \%$ (group II) and $>3 \%$ (group III).

The data collected were employed to perform analysis of variance using the GLM procedure of the SAS package (1989). The statistical model used in the calculations was as follows:

where:

$$
Y_{i j k l}=\mu+a_{i}+b_{j}+g_{k}+\alpha\left(x_{i j k}\right)+e_{i j k l}
$$

$y_{i j k l}-\mathrm{ijkl}^{\text {th }}$ observation,

$\mu$-general mean,

$a_{i}$ - effect of $\mathrm{i}^{\text {th }}$ test station,

$b_{j}-$ effect of $\mathrm{j}^{\text {th }}$ sire,

$g_{k}$ - effect of $1^{\text {th }}$ group (according to division based on IMF level),

$\alpha\left(x_{i j k}\right)$ - covariance on right half-carcass weight (for slaughter traits and IMF),

$e_{i j k l}$ - random error.

Differences between the means for individual breeds were tested for significance at the $5 \%$ and $1 \%$ level by Duncan's multiple range test.

\section{Results}

The indicators used in the study are characterized in Table 1, which also analyses the significance of effects of different variables on these indicators. The tests included two fattening traits and two slaughter traits that can be evaluated on live animals as well as IMF level in the longissimus dorsi muscle. Of the analysed indicators, IMF content showed the highest variation $(\mathrm{V}=37.5 \%)$. The second highest variation $(\mathrm{V}=24.8 \%)$ was found for average backfat thickness from 5 measurements. The lowest variation was observed for carcass meat percentage $(\mathrm{V}=6.0 \%)$. Animal breed had the strongest and highly significant effect on the level of all analysed traits. For age at slaughter and carcass meat percentage, there was an interaction between animal breed and the group factor established based on IMF level $(\mathrm{P} \leq 0.001)$. The factor expressed as IMF group had no effect on the level of the analysed traits $(\mathrm{P}>0.05)$.

The next part of the analysis was to characterize the test material (breed) in terms of the IMF content of the longissimus dorsi muscle (Tables 2 and 3). Analysis of the means from Table 2 concerning animals from different IMF range groups showed comparable distribution for most of the breeds in the $2-3 \%$ and $>3 \%$ IMF groups. The situation was different for animals from the $<2 \%$ IMF group, where unlike the other breeds, Puławska animals were in the upper limit of this range $(1.72 \%$ on average). In general, Puławska and Duroc animals were characterized by the best parameters of this trait and ranked in the group of animals having desirable parameters of meat, i.e. IMF content above $2 \%$ (2.17\% and $2.23 \%$, respectively). The lowest IMF level was found in the loin of Pietrain animals (1.68\%). In the two most popular breeds in Poland, namely Polish Large White and Polish Landrace, IMF levels were similar but below the $2 \%$ level typical of good-quality meat $(1.84 \%$ and $1.76 \%$, respectively). 
Table 1. Characteristics of traits of pig breeds raised in Poland and analysis of the effect of different factors on these traits

\begin{tabular}{l|c|c|c|c|c|c}
\hline \multicolumn{1}{c|}{ Traits } & $\mathrm{n}$ & means & $\pm \mathrm{SE}$ & $\min$. & $\operatorname{max.}$ & $\mathrm{v}$ \\
\hline IMF (\%) & 4436 & 1.83 & 0.68 & 0.30 & 4.60 & 37.5 \\
Age at slaughter (days) & 4436 & 172 & 27.7 & 138 & 226 & 16.0 \\
Daily gain (g) & 4436 & 890 & 120 & 668 & 1236 & 13.5 \\
Average backfat thickness from & & & & & & \\
5 measurements (cm) & 4436 & 1.55 & 0.38 & 0.40 & 3.74 & 24.8 \\
Carcass meat content (\%) & 4436 & 59.3 & 3.55 & 44.9 & 71.0 & 6.00 \\
Loin eye area $\left(\mathrm{cm}^{2}\right)$ & 4436 & 53.8 & 6.86 & 31.2 & 83.4 & 12.7 \\
\hline
\end{tabular}

Table 2. Level of intramuscular fat (IMF) content in different pig breeds according to IMF group $(\mathrm{LSM} \pm \mathrm{SE})$

\begin{tabular}{|c|c|c|c|c|c|c|c|c|c|c|}
\hline \multirow{3}{*}{ Traits } & \multirow{3}{*}{ Breed } & \multicolumn{9}{|c|}{ Ranges of IMF content of longissimus dorsi muscle (IMF; \%) } \\
\hline & & \multicolumn{3}{|c|}{ IMF up to $2 \%$} & \multicolumn{3}{|c|}{ IMF from $2 \%$ to $3 \%$} & \multicolumn{3}{|c|}{ IMF above $3 \%$} \\
\hline & & $\mathrm{n}$ & means & $\pm \mathrm{SE}$ & $\mathrm{n}$ & means & $\pm \mathrm{SE}$ & $\mathrm{n}$ & means & $\pm \mathrm{SE}$ \\
\hline \multirow{7}{*}{$\begin{array}{l}\text { Intramuscul } \\
\text { fat content } \\
(\%)\end{array}$} & PLW & 797 & 1.43 & \pm 0.31 & 363 & 2.36 & \pm 0.28 & 86 & 3.45 & \pm 0.57 \\
\hline & PL & 1448 & 1.41 & \pm 0.32 & 492 & 2.36 & \pm 0.29 & 143 & 3.36 & \pm 0.27 \\
\hline & Puławska & 54 & 1.72 & \pm 0.17 & 40 & 2.44 & \pm 0.29 & 10 & 3.47 & \pm 0.42 \\
\hline & Duroc & 55 & 1.55 & \pm 0.27 & 75 & 2.37 & \pm 0.22 & 22 & 3.41 & \pm 0.30 \\
\hline & Pietrain & 150 & 1.37 & \pm 0.33 & 47 & 2.35 & \pm 0.26 & 11 & 3.33 & \pm 0.17 \\
\hline & L990 & 370 & 1.41 & \pm 0.26 & 171 & 2.45 & \pm 0.30 & 67 & 3.34 & \pm 0.25 \\
\hline & Total & 2874 & 1.42 & $\pm 0.31 \mathrm{AC}$ & 1188 & 2.37 & $\pm 0.28 \mathrm{BC}$ & 339 & 3.39 & $\pm 0.37 \mathrm{AB}$ \\
\hline
\end{tabular}

A, B... - values with the same superscripts show significant differences between groups $(\mathrm{P}<0.01)$.

Analysis of slaughter age in the experimental animals according to the IMF level group showed no statistically significant differences for Polish Large White and Polish Landrace breeds. In the case of Puławska, Duroc and Pietrain breeds, the increasing IMF level was paralleled by higher means for this trait, with mostly significant or highly significant within-breed differences between the groups. An inverse relationship was determined for line 990 gilts, where animals with the lowest IMF levels were the latest to achieve a $100 \mathrm{~kg}$ slaughter weight. When analysing the total results of all breeds for this trait, no significant differences resulting from IMF ranges were found. Likewise, IMF level in all the breeds was unrelated to the rate of growth (daily gains) and to the level of external fat determined from backfat thickness (average of 5 measurements). In addition, there was a statistically significant interaction (Table 1) between breed and IMF group for carcass meat percentage. In the Polish Large White and Polish Landrace breeds, the increasing IMF level was paralleled by a decrease in meat content, with significant differences between the analysed groups. Among Duroc and Puławska gilts, animals with the lowest IMF level ( $<2 \%$ group) were characterized by statistically the lowest carcass meat percentage in relation to the other groups of animals. No marked differences in carcass muscling, resulting from this treatment factor, were observed for the other breeds. 


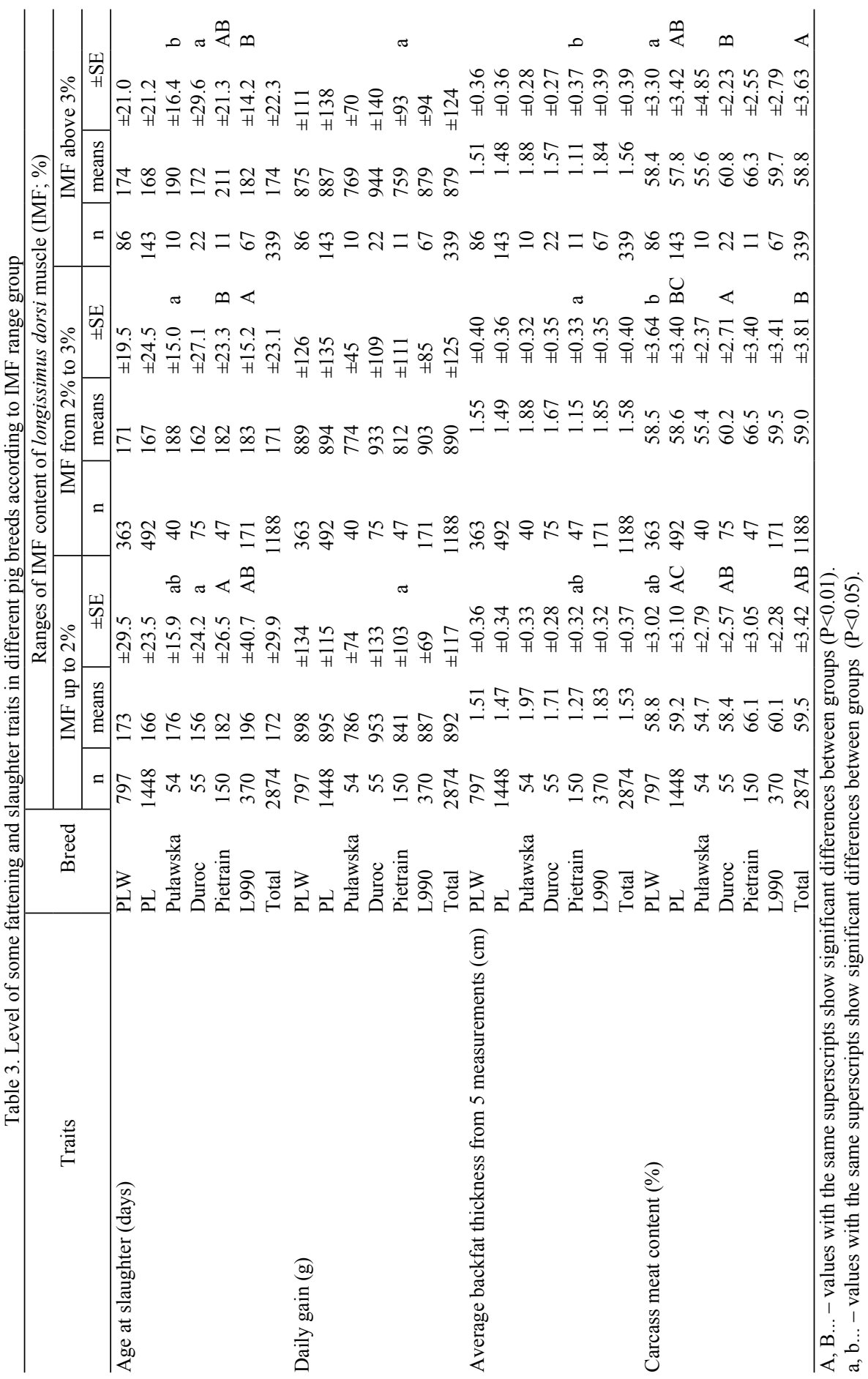




\section{Discussion}

Of the parameters discussed in this study, only IMF content and the level of external fat expressed as average backfat thickness from 5 measurements were characterized by high variation (37.5\% and $24.8 \%$, respectively). However, as regards IMF content, the situation is unfavourable in so far as this parameter is very difficult to estimate objectively on a live animal. The use of magnetic resonance (Villé et al., 1997) or computer tomography (Goodpaster et al., 2004) for this purpose enables this parameter to be estimated with 93-97\% accuracy. However, the use of these techniques for live evaluation is limited by the high cost and lack of equipment portability. For the time being, the use of ultrasound technology (Newcom et al., 2002,2005 ) for this purpose is also impracticable due to the low correlations (from $r_{p}=0.46$ to $\left.r_{p}=0.60\right)$ between the actual IMF level and the level determined from analysis of ultrasound images. For this reason, the aim of the present study was to find out if analysis of parameters determined on live animals could be used to group the animals according to IMF levels, thus providing a basis for selection in this area. However, preliminary statistical analysis of the results (Table 1) for both fattening traits (age at slaughter, daily gains) and slaughter traits (average backfat thickness from 5 measurements, carcass meat content) does not give much hope. Of the three effects included in the linear model (animal breed, IMF group and the breed $\times$ IMF group interaction), only the breed factor had a highly significant effect for all parameters analysed $(\mathrm{P} \leq 0.001)$. No such correlations were found for the group factor resulting from the IMF level. In addition, one unfavourable effect was the statistically significant interaction between animal breed and IMF group for age at slaughter and carcass meat percentage. This makes it impossible to treat the animals of all breeds as one treatment group in this respect.

The fact that no selection factor can be determined for the IMF level within the analysed traits is confirmed by the results of analysis given in Table 3, which showed that in the case of growth rate (daily gains), the animals of two breeds characterized by the extreme values of this parameter, i.e. Duroc $(940 \mathrm{~g})$ and Puławska (780 g) achieved a high average level of IMF content in the longissimus dorsi muscle that exceeded the threshold of good-quality meat ( $2 \%)$. Similarly, the division of animals into groups according to IMF content of $<2 \%, 2-3 \%$ and $>3 \%$ (Table 3 ) in the whole group tested (all breeds together) and in each of the analysed breeds separately did not differentiate the animals in daily gains except the Pietrain animals. The lack of statistical relationships between the above parameters is supported by van Wijk et al. (2005), who obtained low genetic $\left(r_{G}=0.16\right)$ and phenotypic $\left(r_{P}=-0.05\right)$ correlations between these traits. As regards the second parameter under analysis, namely age at slaughter, Puławska, Duroc and Pietrain gilts were characterized by higher IMF levels with the increasing age at slaughter (Table 3). An inverse situation occurred for line 990 animals, and no differences whatsoever were found between the groups of Polish Large White and Polish Landrace animals. Similar observations were reported by Damon et al. (2006), who analysed the level of some factors in two groups of animals with high $(2.82 \%)$ and low $(1.15 \%)$ IMF content and found no significant differences in age at the slaughter weight of $105 \mathrm{~kg}$. The fact that 
these two parameters are unrelated is confirmed by the results of Newcom et al. (2005), who found no phenotypic and genetic relationships between these parameters $\left(r_{\mathrm{P}}=-0.05\right.$ and $\left.\mathrm{r}_{\mathrm{G}}=-0.09\right)$. The two parameters analysed above (growth rate and age at slaughter) are strictly related and it was believed they should differentiate the analysed populations in terms of IMF level. The lack of this effect is probably due to the too low slaughter weight and, to be more exact, to the genetic changes in the pig population in terms of the rate of meat and adipose tissue deposition resulting from directional selection for carcass meatiness. According to Schwab et al. (2007), the modern pig genotype is characterized by a high potential for deposition of meat tissue compared to the genotypes of pigs two decades ago. Unfortunately, the rate of meat tissue deposition is not matched by the rate of IMF deposition, which slowed down according to the authors cited above. As a result, modern animals are quick to reach slaughter weight but their IMF levels are low. This unfavourable relationship between the rate of IMF deposition and the rate of muscle tissue deposition could be corrected by introducing restricted feeding, especially in the initial period of fattening (Heyer and Lebret, 2007). Another method of achieving appropriate IMF levels is to increase slaughter weight, but this would be economically disadvantageous. The unfavourable consequences of this practice would be a decrease in the sensory attributes of the raw material obtained in this way (Candek-Potokar et al., 1998) and an increase in the level of subcutaneous fat, which would be unfavourable from a consumer perspective. On the other hand, a study by Alonso et al. (2010) with two groups of pigs differing in IMF level showed differences in the composition of fatty acids between these groups. However, the same authors found no differences in the sensory parameters of the meat tested by the sensory panel. Likewise, the results of sensory evaluation presented by Czarniecka-Skubina et al. (2007) showed that one group of animals with IMF level exceeding $2.5 \%$ was superior only for 3 sensory parameters (aroma, uniform colour, taste) out of 7 parameters studied.

The analysis of slaughter indicators related to carcass fatness (average backfat thickness, fat percentage) and muscling (loin and ham percentage) in two groups of animals differing in the IMF level showed a significant difference for fatness traits only (Damon et al., 2006). In our study, the groups of animals differing in IMF level showed no differences in the level of external fat. Analogous analysis performed for carcass meat percentage demonstrated that in the Polish Large White, Polish Landrace and Duroc breeds, differences in IMF content caused the above breed groups to differ in carcass meat content, but the observed effect, although statistically significant, was not always directional (as was the case with Polish Large White and Duroc). Our findings in this respect are confirmed by the analogous lack of differences in the level of external fat and carcass meat content depending on the level of IMF in the longissimus dorsi muscle, reported by Czarniecka-Skubina et al. (2007). Likewise, Lonergan et al. (2001) found no significant changes in the marbling level of longisimus dorsi cross-sectional area when analysing differences between two groups of Duroc animals: the control group and the group selected for the rate of meat tissue deposition. The lack of a relationship between carcass meat percentage and IMF is also evidenced by the low genetic $\left(\mathrm{r}_{\mathrm{G}}=-0.28\right)$ and phenotypic correlations $\left(r_{\mathrm{P}}=-0.24\right)$ between these traits (Wijk et al., 2005). The difference in the 
IMF level, assumed by the authors mentioned above (Damon et al., 2006) exceeded $1.7 \%$ and might have helped to detect these differences. In our study, this classification of test material, although feasible, would later have no practical application in the entire Polish population of pigs due to the low frequency of animals with the upper IMF range (Tyra and Żak, 2010), especially among Polish Large White and Polish Landrace animals, in which the increase of this parameter would be the most desirable. The lack of a close relationship between external fat and IMF level is also confirmed by the low genetic correlations between these traits: $r_{G}=-0.03$ and $\mathrm{r}_{\mathrm{G}}=-0.13$, respectively (Suzuki et al., 2005; Cai et al., 2008). In the case of pig breeding, the absence of such relationships is favourable as it enables breeding and selection work to be carried out in two directions at the same time (increasing the level of IMF while reducing the level of external fat).

The results of the analyses presented above do not allow the parameters obtained during live evaluation of animals to be used in selection for improved IMF levels. The high rate of muscle tissue deposition in modern breeds does not allow for genetic differences in IMF level to fully manifest themselves (achievement of optimum IMF level) when slaughter weight is around $100 \mathrm{~kg}$. This unfavourable finding leads one to look for other sources of variation for this trait. It would therefore be appropriate to concentrate on finding selection markers that determine this trait. Positive evidence in this respect is offered by the findings of Pang et al. (2006), Zhao et al. (2010) and Tyra and Ropka-Molik (2011), who analysed the effect of the H-FABP and $A-F A B P$ genes, the products of which take part in the transport of fatty acids. Another direction of research is to look for markers responsible for the differentiation of muscle fibre types. The marbling of meat suggested by Gil et al. (2001) is related to the above type of fibres, which in turn is strictly related to metabolic differences between individual types of muscle fibres. It is concluded that research carried out in these two directions using the Polish population of pigs would allow a broader look in this respect, and the possible positive results could be implemented in the national breeding programme.

\section{References}

Alonso V., Campo Mdel M., Provincial L., Roncalés P., B eltrán J.A. (2010). Effect of protein level in commercial diets on pork meat quality. Meat Sci., 85 (1): 7-14.

$\mathrm{C}$ a i W., C a s e y D.S., D e k k e r s J.C. (2008). Selection response and genetic parameters for residual feed intake in Yorkshire swine. J. Anim. Sci., 86 (2): 287-298.

Candek-Potokar M., Zlender B., Lefaucheur L., B on neau M. (1998). Effects of age and/or weight at slaughter on longissimus dorsi muscle: biochemical traits and sensory quality in pigs. Meat Sci., 48: 287-300.

Czarni ecka-Skubina E., Przybylski W., Jaworska D., W a chowicz I., Ni e my j s ki S. (2007). Quality profile of pork meat with varying contents of intramuscular fat. Żywność. Nauka. Technologia. Jakość, 6 (55): 285-294.

Damon M., Louveau I., Lefaucher L., Lebret B., Vincent A., Leroy P., Sanchez M.P., Herpin P., Gondret F. (2006). Number of intramuscular adipocytes and fatty acid binding protein-4 content are significant indicators of intramuscular fat level in crossbred Large White $\times$ Duroc. J. Anim Sci., 84: 1083-1092. 
Fernandez X., Monin G., Talmant A., Mourot J., Lebret B. (1999). Influence of intramuscular fat content on the quality of pig meat. 2. Consumer acceptability of $\mathrm{m}$. longissimus lumborum. Meat Sci., 53: 67-72.

Gil F., López - A 1 b or s O., Vázquez J.M., Latorre R., R a mír ez - Z a rzos a G., More no F. (2001). The histochemical profiles of fibre types in porcine skeletal muscle. Histol. Histopathol., 16 (2): 439-442.

Go odpast e r B.H., S t enger V.A., B o a d a F., M c Kolan is T., D a vis D., Ros s R., Kel 1 e y D.E. (2004). Skeletal muscle lipid concentration quantified by magnetic resonance imaging. Am. J. Clin. Nutr., 79 (5): 748-754.

Heyer A., L ebret B. (2007). Compensatory growth response in pigs: Effects on growth performance, composition of weight gain at carcass and muscle levels, and meat quality. J. Anim. Sci., 85: 769-778.

K oćw in - P ods i a dła M., Krzę c i o E., Przybyls k i W. (2006). Pork quality and methods of its evaluation - a review. Pol. J. Food Nutr. Sci., 15/56 (3): 217-222.

Lonergan S.M., Huff-Lonergan E., Rowe L.J., Kuhlers D.L., Jungst S.B. (2001). Selection for lean growth efficiency in Duroc pigs influences pork quality. J. Anim. Sci., 79 (8): 2075-2085.

New c om D.W., B a a s.J., M abry J.W., Goodw in R.N. (2002). Genetic parameters for pork carcass components. J. Anim. Sci., 80 (12): 3099-3106.

N ew c o m D.W., B a s s T.J., S chw a b C.R., S t a ld e r K.J. (2005). Genetic and phenotypic relationship between individual subcutaneous backfat layers and percentage of longissimus intramuscular fat in Duroc swine. J. Anim. Sci., 83: 316-323.

P a n g W.J., B a i L., Y a n g G.S. (2006). Relationship among H-FABP gene polymorphism, intramuscular fat content, and adipocyte lipid droplet content in main pig breeds with different genotypes in western China. Acta Genet. Sin., 33, 6: 515-524.

S chwab C.R., B a s T.J., S tald e r K.J., M abry J.W. (2006). Effect of long-term selection for increased leanness on meat and eating quality traits in Duroc swine. J. Anim. Sci., 84: 1577-1583.

S chw ab C.R., B a a s T.J., S t a ld e r K.J., M a b r y J.W. (2007). Deposition rates and accretion patterns of intramuscular fat, loin muscle area, and backfat of Duroc pigs sired by boars from two time periods. J. Anim. Sci., 85 (6): 1540-1546.

Suzuki K., Irie M., Kadowaki H., Shibata T., Kumagai M., Nishida A. (2005). Genetic parameter estimates of meat quality traits in Duroc pigs selected for average daily gain, longissimus muscle area, backfat thickness, and intramuscular fat content. J. Anim. Sci., 83: 2058-2065.

Tyra M., Orzechows k a B. (2006). Effect of age and growth rate on intramuscular fat content of the logissimus dorsi muscle in Polish Landrace and Pulawska pigs. Anim. Sci. (Suppl.), 1: 36-38.

Tyra M., Ropka-Molik K. (2011). Effect of the FAB3 and LEPR gene polymorphism and expression levels on intramuscular fat (IMF) content and fat cover degree in pigs. Livest. Sci., 142: 114-120.

T y r a M., Ż a k G. (2010). Characteristics of the Polish breeding population of pigs in terms of intramuscular fat (IMF) content of $m$. longissimus dorsi. Ann. Anim. Sci., 10 (3): 241-248.

Villé H., Rombouts G., Van Hecke P., Perremans S., Maes G., Spincemaille G., Ge ers R. (1997). An evaluation of ultrasound and nuclear magnetic resonance spectroscopy to measure in vivo intramuscular fat content of longissimus muscle of pigs. J. Anim. Sci., 11: 2942-2949.

Wijk H.J. van, Arts D.J., Matthews J.O., Webster M., Ducro B.J., Knol E.F. (2005). Genetic parameters for carcass composition and pork quality estimated in a commercial production chain. J. Anim. Sci., 83 (2): 324-333.

Zha o S.M., Ren L.J., Chen L., Zhang X., Cheng M.L., Li W.Z., Zhang Y.Y., Gao S.Z. (2010). Differential expression of lipid metabolism related genes in porcine muscle tissue leading to different intramuscular fat deposition. Lipids, 44 (11): 1029-1037. 
MIROSŁAW TYRA, GRZEGORZ ŻAK

\section{Analiza zależności pomiędzy użytkowością tuczną i rzeźną świń a poziomem tluszczu śródmięśniowego (IMF) w mięśniu najdłuższym grzbietu}

\section{STRESZCZENIE}

Celem podjętych badań było określenie wartości podstawowych cech tucznych i rzeźnych (tempa wzrostu, poziomu umięśnienia i otłuszczenia oraz wieku w dniu uboju) w zależności od poziomu tłuszczu śródmięśniowego determinujące odczucia sensoryczne konsumentów. Materiał do badań stanowiło 4430 loszek pochodzących z hodowli zarodowych, które były oceniane w stacjach kontroli. Układ rasowy materiału badawczego był następujący: wbp - 1240 szt., pbz - 2083 szt., puławska - 104 szt., Hampshire - 35 szt., Duroc - 152 szt., Pietrain - 208 szt. i linia 990 - 608 szt. Zwierzęta były utrzymywane w indywidualnych kojcach i żywione standardową mieszanką. Zawartość tłuszczu śródmięśniowego (IMF) w mięśniu najdłuższym grzbietu oznaczano metodą Soxhleta w urządzeniu SOXTHERM SOX 406 firmy Gerhardt. Poziom IMF był podstawą do podziału materiału badawczego na trzy grupy. Grupę pierwszą stanowiły zwierzęta, u których stwierdzono zawartość tłuszczu śródmięśniowego poniżej $2 \%$, drugą grupę stanowiły zwierzęta o zawartości tego tłuszczu w granicach $2-3 \%$, a trzecią powyżej $3 \%$. Na poziom wszystkich analizowanych cech najwyższy i statystycznie wysoko istotny wpływ miała rasa zwierząt. W przypadku wieku uboju i procentowej zawartości mięsa w tuszy stwierdzono interakcję pomiędzy rasą zwierząt a poziomem IMF $(\mathrm{P} \leq 0,001)$. Zawartość IMF nie rzutowała na poziom analizowanych cech $(\mathrm{P}>0,05)$. Tak więc, wyniki przeprowadzonej analizy, odnośnie wskaźników dostępnych z oceny przyżyciowej, nie pozwalają na wykorzystanie tych danych w selekcji na poprawę poziomu IMF. Wysokie tempo odkładania tkanki mięśniowej współczesnych ras nie pozwoliło na pełne zamanifestowanie się różnic genetycznych w zakresie poziomu tłuszczu śródmięśniowego przy masie ubojowej wynoszącej około $100 \mathrm{~kg}$. Ta niekorzystna informacja skłania do poszukiwania innych źródeł warunkowania zmienności tej cechy. 